\title{
PENGARUH TINGKAT PENGGUNAAN MEDIA SOSIAL DAN MOTIVASI TERHADAP MINAT BERWIRAUSAHA PADA MAHASISWA PROGRAM STUDI MANAJEMAN PERGURUAN TINGGI DI KOTA DENPASAR
}

\author{
I Komang Sumerta ${ }^{1}$ \\ Ni Komang Redianingsih ${ }^{2}$ \\ I Made Baji Pranawa ${ }^{3}$ \\ Desak Nyoman Tri Indahyani ${ }^{4}$
}

\author{
Fakultas Ekonomi dan Bisnis Universitas Ngurah Rai Denpasar, Bali, Indonesia ${ }^{1,2,3,4}$ \\ Email: komang.sumerta@unr.ac.id ${ }^{1}$, ningsihdian64@gmail.com²
}

\begin{abstract}
The role of social media is increasingly recognized in boosting business or brand performance. Developing creativity in entrepreneurship among students with the use of social media is a positive impact on the use of social media itself. The purpose of this study was to determine the level of use of social media and motivation towards entrepreneurship interests. This research was conducted at the College of Management Study Program located in the city of Denpasar. The sample used was as many as 100 people active students of management courses in high schools in the city of Denpasar. Data analysis techniques used are Multiple Linear Regression Analysis, Determination Coefficient, F Test and $t$ Test. The results of analysis in this study indicate the level of use of Social Media has a positive and partially significant effect on Entrepreneurial Interest, it can be seen from the t-value of the variable Organizational Commitment is 8.417 is greater than the t-table value of 1.661. Motivation has a positive and partially significant effect on Entrepreneurial Interest, it can be seen from the t-count value of Organizational Culture variables is 5.736 greater than the $t$-table value of 1.661 .
\end{abstract}

Keywords: Level of Use of Social Media; Motivation; Entrepreneurial Interest.

\begin{abstract}
ABSTRAK
Peran media sosial semakin diakui dalam mendongkrak kinerja bisnis ataupun merek. Mengembangkan kreativitas dalam berwirausaha di kalangan mahasiswa dengan penggunaan media sosial menjadi salah satu dampak postif bagi penggunaan media sosial itu sendiri. Tujuan penelitian ini adalah untuk mengetahui tingkat penggunaan media sosial dan motivasi terhadap minat. Penelitian ini dilakukan pada Perguruan Tinggi Program Studi Manajemen yang berlokasi di wilayah Kota Denpasar. Sampel yang digunakan adalah sebanyak 100 orang mahasiswa aktif program studi manajemen perguruan tinngi di kota Denpasar. Teknik analisis data yang digunakan adalah Analisis Regresi Linier Berganda, Koefisien Determinasi, Uji F dan Uji t. Hasil analisi pada penelitian ini menunjukkan Tingkat Penggunaan Media Sosial berpengaruh positif dan signifikan secara parsial terhadap Minat Berwirausaha, hal itu dapat dilihat dari nilai t-hitung variabel Komitmen Organisasi adalah 8,417 lebih besar dari nilai t-tabel 1,661. Motivasi berpengaruh positif dan signifikan secara parsial terhadap Minat Berwirausaha, hal itu dapat dilihat dari nilai t-hitung variabel Budaya Organisasi adalah 5,736 lebih besar dari nilai t-tabel 1,661.
\end{abstract}

Kata kunci: Tingkat Penggunaan Media Sosial; Motivasi; Minat Berwirausaha. 


\section{PENDAHULUAN}

Di era digitalisasi saat ini mungkin apa pun bisa dikaitkan dengan internet. Konsumen juga mulai mengubah perilakunya untuk melakukan pembelanjaan secara online (Sumerta et al., 2019) sehingga seorang wirausahawan harus memikirkan bahwa sosial media merupakan salah satu opsi dalam mengembangkan usaha. Kehadiran internet mengubah cara hidup dan aktivitas manusia sehari-hari. Peran media sosial semakin diakui dalam meningkatkan kinerja bisnis ataupun merek di era saat ini. Pengembangan produk berbasis teknologi yang berdasarkan kebermanfaatan dan kemudahan dalam penggunaan juga memiliki pengaruh yang penting dalam membentuk niat beli konsumen (Sumerta, dkk., 2019). Tetapi dengan terus meningkatnya pengguna internet dari tahun ke tahun, bukan tidak mungkin di masa depan pelaku pemasaran melalui media sosial bakal menyamai wirausahawan yang masih menggunakan cara konvensional untuk memulai bisnis (Sumerta et al., 2019). Mengembangkan kreativitas dalam berwirausaha terutama di kalangan mahasiswa dengan penggunaan media sosial online menjadi salah satu dampak postif bagi penggunaan media sosial itu sendiri.

Wirausahawan berperan sebagai roda penggerak perekonomian sebuah negara. Masyarakat yang berwirausaha memiliki peran penting dalam mewujudkan pertumbuhan ekonomi baik secara mikro untuk memperkecil angka pengangguran maupun secara makro untuk meningkatkan pendapatan perkapita. Namun, jumlah pelaku wirausaha di Indonesia hingga kini masih belum mencapai angka ideal yaitu dua persen dari jumlah penduduk Indonesia (Kompas.com, 2016). 
Menurut data terkini dari Global Entrepreneurship Monitor (GEM) mencatat bahwa Indonesia baru mempunyai sekitar 1,65 persen pelaku wirausaha dari total jumlah penduduk sekitar 250 juta jiwa. Hasil penelitian tentang faktor - faktor yang mempengaruhi minat berwirausaha menunjukkan bahwa variabel minat berwirausaha dipengaruhi sebesar $60,4 \%$ secara total oleh modal, skill, tempat, dan jiwa kewirausahaan Muljaningsih, et al., (2012). Wirausaha merupakan orang yang menciptakan sebuah bisnis yang berhadapan dengan resiko dan ketidakpastian, yang bertujuan memproleh profit dan mengalami pertumbuhan dengan cara mengidentifikasi kesempatan dan memanfaatkan sumber daya yang diperlukan (Ariyanto, 2020). Motivasi untuk mengembangkan usaha baru diperlukan bukan hanya oleh rasa percaya diri dalam hal kemampuannya untuk berhasil, namun juga oleh kemampuannya untuk berhasil, dan juga oleh kemampuannya dalam mengakses informasi mengenai peluang kewirausahaan.

Menurut Myfield (2008), niat berwirausaha didefinisikan sebagai tendensi keinginan individu untuk melakukan tindakan wirausaha dengan menciptakan produk baru berinovasi melalui peluang bisnis dan pengambilan resiko. Untuk itu mahasiswa diharapkan mampu memanfaatkan peluang ini. Modal yang selama ini jadi beban bagi mayoritas mahasiswa bisa sedikit dikurangi dalam pemasaran melalui media sosial.

Pertumbuhan ekonomi suatu negara terus mengalami perubahan secara berkesinambungan selama periode tertentu. Pendidikan merupakan sarana untuk meningkatkan kualitas sumber daya manusia yang berpengaruh terhadap perkembangan seluruh aspek kehidupan. Kualitas sumber daya manusia dapat 
ditingkatkan melalui lembaga pendidikan baik formal maupun nonformal. Peran Perguruan Tinggi dalam hal ini Program Studi Management sangat penting dalam membentuk sifat kepribadian dan kewirausahaan bagi mahasiswa (Adiandari et al., 2019). Mahasiswa S1 Semester VI Program Studi Manajemen Perguruan Tinggi di Kota Denpasar di pilih sebagai objek penelitian karena rata-rata mahasiswa pada semester ini telah mendapatkan mata kuliah kewirausahaan, sehingga dianggap memiliki wawasan tentang kewirausahaan yang cukup dalam menjawab dan mengisi pernyataan pada kuesioner.

Sebagai bahan perbandingan untuk mengetahui jumlah wirausaha pada Mahasiswa Program Studi Mnajemen Perguruan Tinggi Di Kota Denpasar, data yang digunakan adalah data jumlah wirausaha di beberapa perguruan tinggi di kota Denpasar, sesuai yang terlihat pada Tabel 1.

\section{Tabel 1.}

\section{Jumlah Wirausaha Program Studi Manajemen di beberapa Perguruan Tinggi di Kota Denpasar Angkatan Tahun 2016 - 2020}

\begin{tabular}{ccccc}
\hline No & $\begin{array}{c}\text { Nama Perguruan } \\
\text { Tinggi }\end{array}$ & $\begin{array}{c}\text { Jumlah } \\
\text { Mahasiswa }\end{array}$ & $\begin{array}{c}\text { Jumlah Wirausaha } \\
\text { (Orang) }\end{array}$ & $\begin{array}{c}\text { Jumlah } \\
\text { Wirausaha (\%) }\end{array}$ \\
\hline 1 & Universitas Mahasaraswati & 2.377 & 28 & $1,18 \%$ \\
\hline 2 & Universitas Ngurah Rai & 702 & 32 & $4,50 \%$ \\
\hline 3 & Universitas Hindu & 13 & $1,10 \%$ \\
\hline 4 & Indonesia & 1.145 & 33 & $1,30 \%$ \\
\hline 5 & Universitas Warmadewa & 2.453 & 36 & $1,03 \%$ \\
\hline 6 & Universitas Pendidikan & 2.374 & 25 & $1,05 \%$ \\
\hline 7 & Nasional (UNDIKNAS) & & 32 & $6,60 \%$ \\
\hline 8 & Universitas Mahendradata & 481 & 6 & $1,12 \%$ \\
\hline
\end{tabular}

Sumber : https://forlap.ristekdikti.go.id 
Berdasarkan data pada Tabel 1 dapat dilihat sejumlah mahasiswa yang berminat untuk berwirausaha masih sangat sedikit sekali dibandingkan dengan jumlah banyaknya mahasiswa, oleh karena itu perlu adanya dukungan untuk meningkatkan minat berwirausaha di kalangan mahasiswa. Ada beberapa hal penunjang dalam meningkatkan jumlah wirausaha di perguruan tinggi seperti membentuk sebuah UKM (Unit Kegiatan Mahasiswa) salah satunya UKM (Unit Kegiatan Mahasiswa) kewirausahaan. Adanya sarana dan prasarana yang memadai untuk menumbuhkan semangat, aktif melakukan pembelajaran tentang pendidikan kewirausahaan secara teori maupun praktik, dukungan pendanaan dari perguruan tinggi dan bimbingan dari dosen pendamping atau staff pendamping UKM (Unit Kegiatan Mahasiswa).

Pendidikan kewirausahaan dan Motivasi dalam perguruan tinggi diharapkan mampu memunculkan para wirausaha yang kreatif yang bisa menciptakan lapangan kerja dan bisa membantu mengurangi pengangguran yang tak pernah ada habis. Berdasarkan hasil dari wawancara awal dengan beberapa mahasiswa perguruan tinggi di kota denpasar, tidak ada dukungan dari orang tua dan modal awal menyebabkan minat mahasiswa menjadi wirausaha semakin kecil karena kebanyakan orang tua hanya menginginkan anaknya untuk langsung bekerja dan menjadi Pegawai Negeri Sipil (PNS) dengan gaji yang tetap.

Menurut Alma (2014), motivasi dan lingkungan keluarga adalah lingkungan yang dapat mempengaruhi semangat seseorang untuk menjadi wirausaha dapat dilihat dari segi faktor pekerjaan orang tua, misalnya dari orang tua yang bekerja sendiri dan memiliki usaha sendiri, maka cenderung anaknya akan menjadi pengusaha. Untuk 
menjadi seorang wirausaha haruslah tumbuh minat, dan diikuti dengan ketersediaan modal. Minat merupakan perilaku yang muncul sebagai respon terhadap suatu objek yang menunjukkan keinginan pelanggan untuk melakukan sesuat (Kotler \& Keller, 2016). Untuk menumbuhkan minat berwirausaha kepada seorang siswa yaitu dilakukan dengan memberikan motivasi - motivasi dan pengetahuan tentang wirausaha pengalaman untuk terjun secara langsung menjadi seorang wirausaha, dan juga lingkungan yang mendukungnya, baik itu lingkungan sekolah, keluarga maupun masyarakat. Fenomena rendahnya minat berwirausaha menjadi pemikiran serius dari berbagai pihak, baik pemerintah, dunia pendidikan, dunia industri, maupun masyarakat. Berbagai upaya dilakukan untuk menumbuhkan minat berwirausaha terutama merubah pola pikir mahasiswa yang selama ini hanya berminat sebagai pencari kerja apabila telah menyelesaikan kuliah mereka.

Menurut Santoso (2016), minat berwirausaha adalah keinginan dalam diri untuk memenuhi kebutuhan hidup, memajukan usaha atau menciptakan usaha baru dengan kekuatan yang ada pada diri sendiri. Pola pikir yang sebelumnya ingin menjadi karyawan diputar balik menjadi pencari karyawan. Menurut Santoso (2016), minat berwirausaha adalah kecenderungan hati dalam diri subjek untuk tertarik menciptakan suatu usaha yang kemudian mengorganisir, mengatur, menanggung risiko dan mengembangkan usaha yang diciptakannya tersebut. Menurut Schunk et al., (2015), dimensi dan indikator minat berwirausaha sebagai berikut : 1).Sikap umum terhadap aktivitas kewirausahaan yaitu perasaan suka tidak suka, setuju tidak setuju dengan aktivitas kewirausahaan, umumnya terhadap sikap positif atau menyukai 
aktivitaskewirausahaan. 2. Kesadaran spesifik untuk menyukai aktivitas kewirausahaan yaitu memutuskan untuk menyukai aktivitas kewirausahaan. 3. Merasa senang dengan aktivitas kewirausahaan yaitu individu merasa senang dengan segala hal yang berhubungan dengan aktivitas kewirausahaan. 4. Aktivitas kewirausahaan mempunyai arti penting bagi individu yaitu individu merasa bahwa aktivitas kewirausahaan penting bagi hidupnya.

Menurut Cross (2013), "media sosial adalah sebuah istilah yang menggambarkan bermacam-macam teknologi yang digunakan untuk mengikat orangorang ke dalam suatu kolaborasi, saling bertukar informasi dan berinteraksi melalui isi pesan yang berbasis web”. Sedangkan menurut Kotler (2012) "media sosial merupakan perpaduan antara sosiologi dan teknologi yang mengubah monolog (one to many) menjadi dialog dan demokrasi informasi yang mengubah orang-orang dari pembaca konten menjadi penerbit. Menurut Myfield (2008) yang menyatakan ada enam indikator dari sebuah social media yaitu: 1) Partisipasi, Media sosial mendorong kontribusi dan umpan balik (feedback) dari setiap orang yang tertarik. 2) Keterbukaan, Hampir semua pelayan social media terbuka untuk umpan balik dan partisipasi. Mendorong untuk melakukan pemilihan, berkomentar, dan berbagi informasi. 3) Percakapan, Komunikasi yang terjalin antara dua arah, dan dapat didistribusikan ke khalayak tentunya melalui social media tersebut. 4) Komunikasi, Social media memberi peluang komunitas terbentuk dengan cepat dan berkomunikasi secara efektif. Komunitas saling berbagi minat yang sama, misalnya fotografi, isu-isu politik atau program televisi dan radio favorit. 5) Saling Terhubung, Hampir semua social media 
berhasil pada saling terhubung, membuat link pada situs-situs, sumber sumber lain dan orang-orang. 6) Keterampilan siswa menggunakan media sosial.

Selain media sosial Motivasi juga sangat berperan penting, Elqadri, et al., (2015) motivasi adalah perubahan energi dalam diri seseorang yang ditandai dengan munculnya "felling" dan didahului dengan tanggapan terhadap adanya tujuan. Sedangkan Menurut Sari \& Sriathi (2019) motivasi adalah tenaga pendorong atau penarik yang menyebabkan adanya tingkah laku ke arah suatu tujuan tertentu. Menurut Siagian \& Harefa (2019) mengemukakan bahwa: motivasi adalah daya pendorong yang mengakibatkan seseorang anggota organisasi mau dan rela untuk menggerakkan kemampuan dalam membentuk keahlian dan keterampilan tenaga dan waktunya untuk menyelenggarakan berbagai kegiatan yang menjadi tanggung jawabnya dan menunaikan kewajibannya dalam rangka pencapaian tujuan dan berbagai sasaran organisasi yang telah ditentukan sebelumnya. Ada empat indikator motivasi yaitu : 1) Daya pendorong adalah semacam naluri, tetapi hanya suatu dorongan kekuatan yang luas terhadap suatu arah yang umum. 2) Kemauan adalah dorongan untuk melakukan sesuatu karena terstimulasi (ada pengaruh) dari luar diri. 3) Membentuk keahlian adalah proses penciptaan atau pengubahan kemahiran seseorang dalam suatu ilmu tertentu. 4) Tanggung jawab sebagai suatu akibat lebih lanjut dari pelaksanaan peranan, baik peranan itu merupakan hak maupun kewajiban ataupun kekuasaan.

Penelitian tentang pengaruh tingkat penggunaan media sosial dan motivasi terhadap minat berwirausaha, sebelumnya sudah pernah dilakukan. Hasil penelitian 
sejenis yang telah dipublikasikan secara ilmiah digunakan sebagai kajian empiris. Penelitian oleh Kurniawan \& Harti (2013), Menyatakan hasil penelitian menunjukkan pengaruh yang signifikan antara tingkat penggunaan sosial media terhadap minat berwirausaha dengan nilai $t_{\text {hitung }}$ sebesar 6,494 dengan nilai signifikansi 0,000. Tingkat penggunaan sosial media memberikan pengaruh sebesar $21,1 \%$ terhadap minat berwirausaha dan termasuk kategori rendah. Maka dalam penelitian ini dapat disimpulkan bahwa variabel tingkat penggunaan media sosial berpengaruh sangat rendah terhadap minat berwirausaha.

Berdasarkan hasil pengujian hipotesis penelitian Sa'adah \& Mahmud (2019) dapat disimpulkan bahwa variabel penggunaan instagram, efikasi diri, dan motivasi berwirausaha berpengaruh positif dan signifikan terhadap minat berwirausaha baik secara langsung maupun melalui motivasi berwirausaha.

Giantari \& Ramantha (2019) hasil penelitian menunjukkan bahwa motivasi yang meliputi motivasi karir dan ekonomi, lingkungan keluarga, pendidikan akuntansi, serta pendidikan kewirausahaan berpengaruh positif dan signifikan terhadap minat berwirausaha mahasiswa jurusan akuntansi reguler. Penelitian oleh Sumadi \& Sulistyawati (2017) menunjukkan hasil penelitian bahwa sikap, motivasi dan lingkungan berpengarus positif dan signifikan terhadap niat berwirausaha.

Penelitian Praisti \& Rusdarti (2018) menyimpulkan bahwa praktik kerja lapangan, motivasi belajar, dan sosial ekonomi orangtua berpengaruh positif dan signifikan terhadap minat berwirausaha. Berdasarkan hasil penelitian sebelumnya oleh beberapa peneliti di atas,maka dapat disimpulkan bahwa masih ada variabel yang tidak 
berpengaruh positif dan signifikan antara variabel independen terhadap variabel dependen seperti penelitian yang dilakukan oleh Kurniawan \& Harti (2013) dengan hasil penelitian tingkat penggunaan media sosial ada pengaruh signifikan terhadap minat berwirausaha tetapi dengan tingkat yang sangat rendah. Berbeda dengan hasil penelitian yang dilakukan oleh peneliti lainnya bahwa variabel independen yaitu penggunaan media sosial instagram, Motivasi berpengaruh positif dan signifikan terhadap minat berwirausaha. Untuk itu, masih terdapat perdebatan dan perbedaan pendapat secara empiris diantara ke 5 penulis dalam hasil penelitian sebelumnya.

Perdebatan empiris ini memberikan peluang untuk menguji kembali pengaruh tingkat penggunaan media sosial dan motivasi terhadap minat berwirausaha pada mahasiswa program studi manajemen perguruan tinggi di Kota Denpasar. Berdasarkan latar belakang masalah di atas maka penulis tertarik melakukan penelitian dengan judul "Pengaruh Tingkat Penggunaan Media Sosial Dan Motivasi Terhadap Minat Berwirausaha Pada Mahasiswa Program Studi Manajemen Perguruan Tinggi Di Kota Denpasar".

Berdasarkan telaah dan kajian penelitian terdahulu, maka dapat disusun hipotesis sebagai berikut:

$\mathrm{H}_{1}$ : Tingkat penggunaan media sosial berpengaruh positif dan signifikan terhadap minat berwirausaha.

$\mathrm{H}_{2}$ : Motivasi berpengaruh positif dan signifikan terhadap minat berwirausaha.

$\mathrm{H}_{3}$ : Tingkat penggunaan media sosial dan motivasi berpengaruh positif dan signifikan secara simultan terhadap minat berwirausaha. 


\section{METODE PENELITIAN}

Desain penelitian atau jenis penelitian yang digunakan dalam penelitian ini adalah penelitian kuantitatif. Menurut Sugiyono (2017;55) metode penelitian kuantitatif dapat diartikan sebagai metode penelitian yang berlandaskan pada filsafat positivesme, digunakan untuk meneliti pada populasi atau sampel tertentu, teknik pengambilan sampel pada umumnya dilakukan secara random, pengumpulan data menggunakan instrumen penelitian, analisis data bersifat kuantitatif/statistik dengan tujuan untuk menguji hipotesis yang telah ditetapkan. Penelitian ini dilakukan pada Perguruan Tinggi Program Studi Manajemen yang berlokasi di Seputaran wilayah Kota Denpasar, Bali, Indonesia.

Populasi dalam penelitian ini adalah seluruh mahasiswa semester VI Program Studi Manajemen Perguruan Tinggi di Kota Denpasar tahun ajaran 2019/2020 yang jumlahnya sebanyak 11.190 orang. Teknik pengambilan sampel dalam penelitian ini penulis menggunakan probability sampling. Teknik purposive random sampling adalah teknik penentuan sampel dengan acak dengan pertimbangan atau kreteria tertentu. Penelitian ini menggunakan rumus slovin dalam penentuan sampel.

$$
\begin{aligned}
& \mathrm{n}=\frac{11.190}{1+11.190(10)^{2}} \\
& \mathrm{n}=\frac{11.190}{112.9}=99.1
\end{aligned}
$$

Sehingga sampel dalam penelitian ini dibulatkan menjadi 100 sampel. Pengumpulan data dalam penelitian ini selanjutnya dilakukan dengan menggunakan 
metode observasi, kuesioner, dan study dokumentasi. Alat analisis yang dipergunakan dalam penelitian ini adalah uji asumsi klasik, analisis regresi linier berganda, analisis determinasi. Mempermudah perhitungan tersebut bantuan program komputer berupa program SPSS version 22 for windows. Uji Asumsi Klasik dalam penelitian ini yang pertama Uji Normalitas yaitu Pengujian Normalitas dilakukan dengan Uji One Sample Kolmogorov-Smirnov dengan menggunakan taraf signifikan 5\%, dimana data dikatakan berdistribusi normal apabila signifikansi lebih besar dari 0,05.

\section{HASIL DAN PEMBAHASAN}

Sebaran responden yang beragam akan mampu memberikan data yang lebih akurat dalam pengujian statistik yang digunakan. Data hasil penelitian diperoleh dari hasil kuesioner yang telah disebarkan kepada responden penelitian sejumlah 100 orang. Karakteristik responden meliputi jenis kelamin dan usia dapat dilihat pada Tabel 2.

Tabel 2.

Karakteristik Responden Mahasiswa Smester VI Program Studi Manajemen Perguruan Tinggi Di Kota Denpasar.

\begin{tabular}{ccccc}
\hline No. Karakteristik & Klasifikasi & $\begin{array}{c}\text { Jumlah } \\
\text { Responden } \\
\text { (orang) }\end{array}$ & $\begin{array}{c}\text { Presentase } \\
\text { Responden } \\
(\mathbf{\%})\end{array}$ \\
\hline 1. & Jenis Kelamin & Laki-laki & 44 & 44 \\
& & Perempuan & 56 & 56 \\
\hline 2. & Usia/Umur & 19-25 tahun & 52 & 52 \\
& & 26-30 tahun & 38 & 38 \\
& & $>31$ tahun & 10 & 10 \\
\hline
\end{tabular}

Sumber : Mahasiswa Program Studi Manajemen Perguruan Tinggi Kota Denpasar, 2020

Tabel 2 menunjukkan bahwa mayoritas responden yang minat berwirausaha 
yaitu berjenis kelamin perempuan, memiliki rentang usia 19 sampai 25 tahun yang berstatus mahasiswa aktif. Deskripsi jawaban responden menyajikan penilaian responden terhadap setiap butir-butir pernyataan yang diajukan dalam kuesioner. Skala pengukuran yang dipergunakan mulai dari 1 sampai dengan 5. Semakin tinggi nilai rata-rata yang diperoleh menunjukkan semakin baik tanggapan responden terhadap item maupun variabel tersebut.

Tabel 3.

Deskripsi Penilaian RespondenTerhadap Tingkat Penggunaan Media Sosial

\begin{tabular}{|c|c|c|c|c|c|c|c|c|}
\hline \multirow[t]{2}{*}{ No } & \multirow[t]{2}{*}{ Pernyataan } & \multicolumn{5}{|c|}{$\begin{array}{l}\text { Jumlah Jawaban } \\
\text { (responden) }\end{array}$} & \multirow{2}{*}{$\begin{array}{l}\text { Rata } \\
\text { - } \\
\text { Rata } \\
\text { Skor }\end{array}$} & \multirow[t]{2}{*}{$\begin{array}{l}\text { Kategori } \\
\text { Penilaian }\end{array}$} \\
\hline & & SS & $\mathbf{S}$ & $\mathbf{N}$ & $\mathbf{T S}$ & STS & & \\
\hline 1 & $\begin{array}{l}\text { Penggunaan media sosial sangat } \\
\text { berperan dalam kegiatan } \\
\text { berwirausaha }\end{array}$ & 30 & 51 & 17 & 2 & - & 4,09 & Tinggi \\
\hline 2 & $\begin{array}{l}\text { Penggunaan media sosial bisa } \\
\text { sangat berperan dalam } \\
\text { melakukan pencarian dan } \\
\text { berbagi informasi }\end{array}$ & 21 & 58 & 21 & - & - & 4,00 & Tinggi \\
\hline 3 & $\begin{array}{l}\text { Penggunaan media sosial yang } \\
\text { menumbuhkan komunikasi } \\
\text { antara dua arah yang berbeda } \\
\text { menjadi satu percakapan yang } \\
\text { memiliki tujuan yang sama. }\end{array}$ & 17 & 45 & 30 & 8 & - & 3,71 & Tinggi \\
\hline 4 & $\begin{array}{l}\text { Penggunaan media sosial dapat } \\
\text { memberi peluang komunitas } \\
\text { untuk berkomunikasi secara } \\
\text { efektif dan saling berbagi }\end{array}$ & 23 & 36 & 39 & 2 & - & 3,80 & Tinggi \\
\hline 5 & $\begin{array}{l}\text { Penggunaan media sosial bisa } \\
\text { saling terhubung satu sumber } \\
\text { dengan yang lainnya }\end{array}$ & 3 & 88 & 8 & 1 & - & 3,93 & Tinggi \\
\hline \multirow[t]{3}{*}{6} & $\begin{array}{l}\text { Penggunaan media sosial dapat } \\
\text { menumbuhkan keterampilan } \\
\text { dalam melakukan kegiatan }\end{array}$ & 19 & 44 & 32 & 5 & - & 3,77 & Tinggi \\
\hline & Jumlah Skor & & & & & & 23,30 & Tinggi \\
\hline & \multicolumn{4}{|c|}{ Rata - Rata Skor } & & & 3,88 & \\
\hline
\end{tabular}

Sumber : Pengolahan data penelitian, 2020 
Hasil analisis deksriptif sebagaimana disajikan pada Tabel 3 menunjukkan bahwa variabel tingkat penggunaan media social secara keseluruhan memperoleh nilai rata-rata sebesar 3,88, yang berarti penilaian responden dalam kategori Baik. Dimana skor jawaban tertinggi berada pada pernyataan pertama yaitu "Penggunaan media sosial sangat berperan dalam kegiatan berwirausaha" dan skor jawaban terendah berada pada pernyataan ketiga yaitu "Penggunaan media sosial yang menumbuhkan komunikasi antara dua arah yang berbeda menjadi satu percakapan yang memiliki tujuan yang sama”. Dengan berkembangnya teknologi saat ini ditunjang dengan adanya media sosial yang dapat memfasilitasi setiap orang untuk selalu terhubung satu sama lain. Maka menjual maupun mempromosikan barang-barang dapat dilakukan dengan cara yang lebih cepat dan memangkas biaya seminimal mungkin. Hal inilah yang membuat penggunaan media sosial merupakan hal yang paling penting untuk para mahasiswa menjalankan bisnisnya.

Tabel 4.

Deskripsi Penilaian RespondenTerhadap Variabel Motivasi

\begin{tabular}{|c|c|c|c|c|c|c|c|c|}
\hline \multirow[t]{2}{*}{ No } & \multirow[t]{2}{*}{ Pernyataan } & \multicolumn{5}{|c|}{$\begin{array}{c}\text { Jumlah Jawaban } \\
\text { (responden) }\end{array}$} & \multirow{2}{*}{$\begin{array}{l}\text { Rata- } \\
\text { Rata } \\
\text { Skor }\end{array}$} & \multirow[t]{2}{*}{$\begin{array}{l}\text { Kategori } \\
\text { Penilaian }\end{array}$} \\
\hline & & SS & $\mathbf{S}$ & $\mathbf{N}$ & TS & STS & & \\
\hline 1 & $\begin{array}{l}\text { Seseorang wirausaha harus } \\
\text { mempunyai semangat tinggi } \\
\text { dan mau berjuang untuk maju }\end{array}$ & 29 & 52 & 16 & 3 & - & 4,07 & Tinggi \\
\hline 2 & $\begin{array}{l}\text { Seorang wirausaha tidak } \\
\text { terikat, memiliki banyak } \\
\text { waktu serta bertindak bebas } \\
\text { dari tekanan }\end{array}$ & 27 & 44 & 24 & 5 & - & 3,93 & Tinggi \\
\hline 3 & $\begin{array}{l}\text { Saya berani membuka usaha } \\
\text { walaupun terdapat resiko ke } \\
\text { gagalan }\end{array}$ & 10 & 55 & 30 & 5 & - & 3,70 & Tinggi \\
\hline
\end{tabular}

Bersambung 


\section{Lanjutan}

\section{Tabel 4.}

Deskripsi Penilaian RespondenTerhadap Variabel Motivasi

\begin{tabular}{|c|c|c|c|c|c|c|c|c|}
\hline \multirow[t]{2}{*}{ No } & \multirow[t]{2}{*}{ Pernyataan } & \multicolumn{5}{|c|}{$\begin{array}{l}\text { Jumlah Jawaban } \\
\text { (responden) }\end{array}$} & \multirow{2}{*}{$\begin{array}{l}\text { Rata- } \\
\text { Rata } \\
\text { Skor }\end{array}$} & \multirow[t]{2}{*}{$\begin{array}{l}\text { Kategori } \\
\text { Penilaian }\end{array}$} \\
\hline & & SS & $\mathbf{S}$ & $\mathbf{N}$ & TS & STS & & \\
\hline 4 & $\begin{array}{l}\text { Dalam memiliki prestasi saya } \\
\text { lebih mudah dalam menjadi } \\
\text { wirausaha }\end{array}$ & 9 & 58 & 29 & 4 & - & 3,72 & Tinggi \\
\hline 5 & $\begin{array}{l}\text { Orang-orang kreative adalah } \\
\text { mereka yang gagal ratusan } \\
\text { kali,tetapi mereka mengambil } \\
\text { pekerjaan dari kegagalan } \\
\text { sebagai peluang mencoba lagi } \\
\text { dengan cara lebih baik }\end{array}$ & 12 & 53 & 32 & 3 & - & 3,74 & Tinggi \\
\hline 6 & $\begin{array}{l}\text { Seseorang wirausaha harus } \\
\text { memiliki sifat aktive dalam } \\
\text { mengontrol atau terlibat } \\
\text { langsung dalam memberikan } \\
\text { keputusan pada usahanya }\end{array}$ & 28 & 51 & 19 & 2 & & 4,05 & Tinggi \\
\hline & Jumlah Skor & & & & & & 23,21 & Tinggi \\
\hline & Rata - & ta $\mathrm{Sl}$ & & & & & 3,87 , & Tinggi \\
\hline
\end{tabular}

Sumber : Pengolahan data penelitian, 2020

Hasil analisis deskripsi sebagaimana disajikan pada Tabel 4 menunjukkan bahwa variabel motivasi secara keseluruhan memperoleh nilai rata-rata adalah 3,87, yang berarti penilaian responden dalam kategori Tinggi- Dimana skor jawaban tertinggi berada pada pernyataan pertama yaitu "Seseorang wirausaha harus mempunyai semangat tinggi dan mau berjuang untuk maju" dan skor dengan jawaban terendah berada pada pernyataan ketiga yaitu "Saya berani membuka usaha walaupun terdapat resiko ke gagalan”. Motivasi merupakan faktor internal yang paling utama dalam mendorong minat berwirasauha. Motivasi dapat timbul karena adanya dukungan dari luar seperti adanya mata kuliah dan pelatihan khusus tentang berwirausaha. 
Adanya mata kuliah serta kegiatan pelatihan tentang berwirausaha dilingkungan kampus merupakan hal yang sangat diinginkan mahasiwa ditengah sedikitnya peluang untuk bekerja diperusahaan.

\section{Tabel 5.}

\section{Deskripsi Penilaian RespondenTerhadap Minat Berwirausaha}

\begin{tabular}{|c|c|c|c|c|c|c|c|c|}
\hline \multirow[t]{2}{*}{ No } & \multirow[t]{2}{*}{ Pernyataan } & \multicolumn{5}{|c|}{$\begin{array}{l}\text { Jumlah Jawaban } \\
\text { (responden) }\end{array}$} & \multirow{2}{*}{$\begin{array}{l}\text { Rata- } \\
\text { Rata } \\
\text { Skor }\end{array}$} & \multirow[t]{2}{*}{$\begin{array}{l}\text { Kategori } \\
\text { Penilaian }\end{array}$} \\
\hline & & SS & $\mathbf{S}$ & $\mathbf{N}$ & TS & STS & & \\
\hline 1 & $\begin{array}{l}\text { Saya berani menjadi wirausaha } \\
\text { karena tidak memiliki tanggung } \\
\text { jawab pekerjaan pada orang lain }\end{array}$ & 37 & 46 & 16 & 1 & - & 4,19 & Tinggi \\
\hline 2 & $\begin{array}{l}\text { Saya berminat menjadi wirausaha } \\
\text { karena bebas melakukan } \\
\text { pekerjaan }\end{array}$ & 37 & 44 & 18 & 1 & - & 4,17 & Tinggi \\
\hline 3 & $\begin{array}{l}\text { Saya berminat menjadi } \\
\text { wirausaha karena dapat } \\
\text { membantu mengurangi jumlah } \\
\text { pengangguran di masyarakat }\end{array}$ & 17 & 51 & 28 & 4 & - & 3,81 & Tinggi \\
\hline 4 & $\begin{array}{l}\text { Saya berminat menjadi } \\
\text { wirausaha karena dapat } \\
\text { menciptakan lapangan } \\
\text { pekerjaan buat orang lain }\end{array}$ & 17 & 53 & 26 & 4 & - & 3,83 & Tinggi \\
\hline 5 & $\begin{array}{l}\text { Saya berminat menjadi } \\
\text { wirausaha karena dengan } \\
\text { berwirausaha saya dapat } \\
\text { menjadi motivasi untuk orang- } \\
\text { orang sekitar }\end{array}$ & 19 & 52 & 27 & 2 & - & 3,88 & Tinggi \\
\hline 6 & $\begin{array}{l}\text { Saya merasa senang apabila } \\
\text { saya berwirausaha }\end{array}$ & 32 & 50 & 18 & 9 & - & 4,14 & Tinggi \\
\hline & Jumlah Skor & & & & & & $2^{24,0}$ & Tinggi \\
\hline & Rata - Rata & kor & & & & & 4,00 & \\
\hline
\end{tabular}

Sumber: Pengolahan data penelitian, lampiran 2

Hasil analisis deskripsi Tabel 5 menunjukkan rata-rata skor untuk variabel Minat Berwirausaha adalah 4.00, yang berarti penilaian responden dalam kategori Baik. Dimana skor jawaban tertinggi berada pada pernyataan pertama yaitu "Saya berani menjadi wirausaha karena tidak memiliki tanggung jawab pekerjaan pada orang 
lain" dan skor jawaban terendah berada pada pernyataan ketiga yaitu "Saya berminat menjadi wirausaha karena dapat membantu mengurangi jumlah pengangguran di masyarakat". Menjadi seorang wirasuaha akan membuat mahasiswa menjadi lebih mandiri, artinya mereka sendiri yang mengatur bagaimana proses usaha itu berlangsung. Semakin berusaha lebih keras maka hasil yang diterimapun semakin lebih banyak. Mahasiswa akan lebih nyaman untuk bekerja karena tidak adanya ikatan oleh aturan perusahaan dan tanggung jawab terhadap orang lain. Berdasarkan wawancara dengan mahasiswa, menjadi seorang wirausaha masih hanya sebatas untuk memenuhi penghasilan mereka sendiri, untuk itu belum banyak mahasiswa yang memulai bisnis untuk tujuan menyerap tenaga kerja lain.

Hasil penelitan dengan menggunakan program SPSS version 22 for windows uji dengan menggunakkan Kolmogorov-Smirnov nilai Asymp. Sig diperoleh sebesar 0,200 $>0,05$. Berdasarkan hasil tersebut dapat disimpulkan bahwa data dalam penelitian ini berdistribusi secara normal. Yang kedua yaitu Uji Multikolinearitas yaitu ketentuan dengan melihat nilai Tolerence Value $\leq 0,10$ serta koefisien VIF (Variance Inflation Factor) bernilai $\geq 10$. Jika VIF (Variance Inflation Factor) $\geq 10$ dan Tolerence Value $\leq 0,10$ maka terjadi gejala multikolinearitas. Jika VIF (Variance Inflation Factor) $\leq 10$ dan Tolerence Value $\geq 0,10$ maka model terbebas dari multikolinearitas dan dapat digunakan dalam suatu penelitian. Nilai Tolerence Value dan VIF (Variance Inflation Factor) untuk masing-masing variabel, menurut Sekaran (2017: 47).

Hasil penelitan dengan menggunakan program SPSS version 22 for windows, menunjukkan bahwa semua variabel memiliki Tolerence Value $\geq 0,10$ yaitu variabel 
Tigkat Penggunaan Media Sosial 0,248, dan variabel Motivasi 0,248 Selain itu, semua variabel memiliki nilai VIF (Variance Inflation Factor) $\leq 10$, yaitu yaitu variable Tingkat Penggunaan Media Sosial 4,031 dan variabel Motivasi 4,031. Dengan demikian dapat disimpulkan bahwa dalam penelitian ini terbebas dari multikolinearitas atau tidak terjadi multikolinearitas. Uji Asumsi Klasik yang ketiga yaitu Uji Heteroskedastisitas yaitu model regresi yang baik adalah yang tidak terjadi heteroskedastisitas. Ketentuan tidak mengandungadanya heteroskedastisitas yaitu jika nilai probabilitas signifikansi $>0,05$.

Hasil penelitan dengan menggunakan program SPSS version 22 for windows yaitu, nilai signifikasi variabel Tingkat Penggunaan Media Sosial $\left(X_{1}\right)$ sebesar 0,996 > 0,05 dan nilai signifikansi variabel promosi $\left(\mathrm{X}_{2}\right)$ sebesar $0,818>0,05$, artinya bahwa tidak terjadi gejala heteroskedastisitas pada variabel Tingkat Penggunaan Media Sosial $\left(\mathrm{X}_{1}\right)$ dan variable Motivasi $\left(\mathrm{X}_{2}\right)$. Berikutnya yaitu Analisis Regresi Liner Berganda, berdasarkan nilai-nilai yang diperoleh dalam pengolahan data menggunakan program SPSS version 22 for windows, maka persamaan regresi linier berganda akan menjadi : $Y=0,579 X_{1}+0,394 X_{2}$

Berdasarkan persamaan regresi linier berganda tersebut, diperoleh persamaan garis regresi yang memberikan informasi bahwa :

$\mathrm{b}_{1}=0,579$, artinya apabila Motivasi dianggap konstan atau nilainya tetap, maka meningkatnya Tingkat Penggunaan Media Sosial sebesar satu satuan akan diikuti oleh meningkatnya Minat Berwirausaha sebesar 0,579.

$\mathrm{b}_{2}=0,394$, artinya apabila Tingkat Penggunaan Media Sosial dianggap konstan atau 
nilainya tetap, maka meningkatnya Motivasi sebesar satu satuan akan diikuti oleh meningkatnya Minat Berwirausaha sebesar 0,394.

Analisis yang selanjutnya yaitu Analisis Determinasi berdasarkan nilai-nilai yang diperoleh dalam pengolahan data menggunakan program SPSS version 22 for windows, hasil perhitungan dengan SPSS diperoleh nilai koefisien determinasi $(R$ Square) adalah 0,884. Ini berarti besarnya kontribusi atau sumbangan Tingkat Penggunaan Media Sosial dan Motivasi terhadap Minat Berwirausaha adalah 88,4\% sedangkan sisanya 11,6\% dipengaruhi oleh variabel lain di luar Tingkat Penggunaan Media Sosial dan Motivasi yang tidak dibahas dalam penelitian ini.

Berikutnya teknik analisis Uji t-test, Uji ini digunakan untuk menguji apakah ada pengaruh secara parsial antara Tingkat Penggunaan Media Sosial Dan Motivasi Terhadap Minat Berwirausaha. Variabel yang pertama yaitu Tingkat Penggunaan Media Sosial. Hasil analisi Uji t-tes dapat di lihat pada Tabel 6. Berdasarkan hasil data yang diolah menggunakan aplikasi SPSS dapat dijelaskan bahwa t-tabel Dengan menggunakan uji satu sisi pada tingkat kesalahan 5\% $(0,05)$, dimana $\mathrm{n}=34$ dan $\mathrm{k}=4$. Didapat derajat kebebasan $(\mathrm{df})=\mathrm{n}-\mathrm{k}=100-3=97$, sehingga diperoleh nilai t-tabel adalah $\mathrm{t}_{0.05(97)}=1,661$. Nilai $\mathrm{t}_{1}$-hitung 8,417 lebih besar dari nilai t-tabel 1,661, dan $\mathrm{t}$ hitung berada pada daerah penolakan $\mathrm{H} 0$, oleh karena itu $\mathrm{H} 0$ ditolak dan Ha diterima. Sehingga dapat disimpulkan bahwa Tingkat Penggunaan Media Sosial secara parsial mempunyai pengaruh yang positif dan signifikan terhadap Minat Berwirausaha. Maka hipotesis yang menyatakan "Tingkat Penggunaan Media Sosial secara parsial 
berpengaruh positif dan signifikan terhadap Minat Berwirausaha Pada Mahasiswa Program Studi Manajemen Perguruan Tinggi Di Kota Denpasar” dapat diterima.

Tabel 6.

Hasil Analisis Uji t-Test

\begin{tabular}{|c|c|c|c|c|c|c|}
\hline \multicolumn{7}{|c|}{ Coefficients $^{\mathbf{a}}$} \\
\hline \multirow{2}{*}{\multicolumn{2}{|c|}{ Model }} & \multicolumn{2}{|c|}{$\begin{array}{l}\text { Unstandardized } \\
\text { Coefficients }\end{array}$} & \multirow{2}{*}{$\begin{array}{c}\begin{array}{c}\text { Standardized } \\
\text { Coefficients }\end{array} \\
\text { Beta }\end{array}$} & \multirow[t]{2}{*}{$\mathbf{T}$} & \multirow[t]{2}{*}{ Sig. } \\
\hline & & B & $\begin{array}{l}\text { Std. } \\
\text { Error }\end{array}$ & & & \\
\hline \multirow[t]{3}{*}{1} & (Constant) & .691 & .872 & & .792 & .430 \\
\hline & $\begin{array}{l}\text { Tingkat } \\
\text { Penggunaan Media } \\
\text { Sosial }\end{array}$ & .625 & .074 & .579 & 8.417 & .000 \\
\hline & Motivasi & .378 & .066 & .394 & 5.736 & .000 \\
\hline
\end{tabular}

Sumber: Pengolahan Data Penelitian, 2020

Variabel yang kedua yaitu Motivasi, Berdasarkan hasil data yang diolah menggunakan aplikasi SPSS dapat dijelaskan bahwa nilai t2-hitung 5,736 lebih besar dari nilai t-tabel 1,661, dan t hitung berada pada daerah penolakan $\mathrm{H} 0$, oleh karena itu H0 ditolak dan Ha diterima. Sehingga dapat disimpulkan bahwa Motivasi secara parsial mempunyai pengaruh yang po sitif dan signifikan terhadap Minat Berwirausaha. Maka hipotesis yang menyatakan "Motivasi secara parsial berpengaruh positif dan signifikan terhadap Minat Berwirausaha Pada Mahasiswa Program Studi Manajemen Perguruan Tinggi Di Kota Denpasar" dapat diterima.

Berikutnya teknik analisis Uji F-test Uji ini digunakan untuk membuktikan apakah Tingkat Penggunaan Media Sosial dan Motivasi secara simultan mempunyai pengaruh terhadap Minat Berwirausaha. Hasil analisis uji F dapat dilihat pada Tabel 7. 
ISSN : 2337-3067

E-Jurnal Ekonomi dan Bisnis Universitas Udayana 9.7 (2020):627-652

Tabel 7.

Hasil Analisis Uji F

\begin{tabular}{ccccccc}
\hline \multirow{2}{*}{ Model } & \multicolumn{5}{c}{ ANOVA $^{\mathbf{a}}$} & \\
\hline 1 & & $\begin{array}{c}\text { Sum of } \\
\text { Squares }\end{array}$ & Df & $\begin{array}{c}\text { Mean } \\
\text { Square }\end{array}$ & F & Sig. \\
& $\begin{array}{c}\text { Regressio } \\
\mathrm{n}\end{array}$ & 1269.082 & 2 & 634.541 & 377. & $.000^{\mathrm{b}}$ \\
\cline { 2 - 7 } & & & & & 893 & \\
\cline { 2 - 7 } & Residual & 162.878 & 97 & 1.679 & & \\
\cline { 2 - 7 } & Total & 1431.960 & 99 & & & \\
\hline
\end{tabular}

Sumber: Pengolahan Data Penelitian, 2020

Berdasarkan hasil analisis SPSS dengan menggunakan tingkat kesalahan 5\% $(0,05)$, dimana $\mathrm{n}=100$ dan $\mathrm{k}=3$. Didapat derajat kebebasan untuk penyebut $(\mathrm{df})=\mathrm{k}$ $-1=3-1=2$, dan derajat kebebasan untuk pembilang $(\mathrm{df})=\mathrm{n}-\mathrm{k}=100-3=97$, sehingga diperoleh nilai F-tabel adalah $\mathrm{F}_{0,05(2: 30)}=3,09$.

Berdasarkan hasil data yang diolah menggunakan aplikasi SPSS dapat dijelaskan bahwa nilai F-hitung 377.893 lebih besar dari nilai F-tabel 3,09, dan F hitung berada pada daerah penolakan $\mathrm{H} 0$, oleh karena itu $\mathrm{H} 0$ ditolak dan Ha diterima. Sehingga dapat disimpulkan bahwa Tingkat Penggunaan Media Sosial dan Motivasi secara simultan mempunyai pengaruh yang positif dan signifikan terhadap Minat Berwirausaha. Maka hipotesis yang menyatakan "Tingkat Penggunaan Media Sosial dan Motivasi secara simultan berpengaruh positif dan signifikan terhadap Minat Berwirausaha Pada Mahasiswa Program Studi Manajemen Perguruan Tinggi Di Kota Denpasar" dapat diterima.

Secara parsial Tingkat Penggunaan Media Sosial berpengaruh positif dan signifikan terhadap Minat Berwirausaha Pada Mahasiswa Program Studi Manajemen 
Perguruan Tinggi Di Kota Denpasar. Hal ini mendukung beberapa penelitian sebelumnya oleh Adiandari, et al., (2019); Ariyanto, et al., (2014); Kurniawan \& Harti (2013); Sa’adah \& Mahmud (2019) yang menemukan bahwa Tingkat Penggunaan Media Sosial berpengaruh signifikan terhadap Minat Berwirausaha Pada Mahasiswa Pendidikan Ekonomi Universitas Negeri Surabaya.

Secara parsial Motivasi berpengaruh positif dan signifikan terhadap Minat Berwirausaha Pada Mahasiswa Program Studi Manajemen Perguruan Tinggi Di Kota Denpasar. Hal ini mendukung penelitian sebelumnya oleh Giantari \& Ramantha (2019); Sa'adah \& Mahmud (2019); Sumadi \& Sulistyawati (2017) yang menemukan bahwa Motivasi berpengaruh positif terhadap Minat Berwirausaha Pada Mahasiswa Fakultas Ekonomi Di PTN Se-Kota Semarang.

Tingkat Penggunaan Media Sosial dan Motivasi berpengaruh positif dan signifikan secara simultan terhadap Minat Berwirausaha Pada Mahasiswa Program Studi Manajemen Perguruan Tinggi Di Kota Denpasar. Hal ini mendukung penelitian sebelumnya oleh Alfaruk (2017); Ariyanto (2020); Praisti \& Rusdarti (2018); Sa'adah \& Mahmud (2019); Sumerta, et al., (2019) yang menemukan bahwa Pemanfaat Sosial Media,Motivasi dan Pengetahuan Terhadap Minat Berwirausaha Pada Mahasiswa Ekonomi.

\section{SIMPULAN DAN SARAN}

Berdasarkan rumusan masalah dan analisis data yang telah dilakukan serta pembahasan yang dikemukakan sebelumnya, maka dapat ditarik kesimpulan dari 
penelitian ini bahwa Penggunaan Media Sosial berpengaruh positif dan signifikan secara parsial terhadap Minat Berwirausaha. Hal tersebut juga menunjukkan bahwa semakin meningkat Tingkat Penggunaan Media Sosial maka Minat Berwirausaha pada Mahasiswa Program Studi Manajemen Perguruan Tinggi di Kota Denpasar juga akan meningkat. Motivasi berpengaruh positif dan signifikan secara parsial terhadap Minat Berwirausaha. Hal tersebut juga menunjukkan bahwa semakin meningkat Motivasi maka Minat Berwirausaha pada Mahasiswa Program Studi Manajemen Perguruan Tinggi di Kota Denpasar juga akan meningkat. Tingkat Penggunaan Media Sosial dan Motivasi berpengaruh positif dan signifikan secara simultan terhadap Minat Berwirausaha. Hal tersebut juga menunjukkan bahwa semakin meningkat Tingkat Penggunaan Media Sosial dan Motivasi secara bersama - sama maka akan meningkatkan Minat Berwirausaha pada Mahasiswa Program Studi Manajemen Perguruan Tinggi di Kota Denpasar.

Berdasarkan hasil penelitian dan kesimpulan yang telah dibuat maka saransaran yang dapat diajukan berkaitan dengan penelitian ini adalah disarankan kepada mahasiswa untuk dapat menggunakan metode dua arah didalam membangun bisnisnya dengan memaksimalkan penggunaan media sosial. Mahasiswa diharapkan mampu mengikuti dan mengimplementasikan teori - teori kewirausahaan yang diajarkan di kampus untuk mengembangkan usahanya kedepan, hal ini dikarenakan pendidikan kewirausahaan memiliki peran penting dalam menumbuhkan motivasi mahasiswa untuk berwirausaha. Mahasiswa yang beriwausaha untuk mampu terus mengembangkan kemampuan serta melebarkan bisnisnya. Semakin besar bisnis yang 
dimiliki tentu akan semakin besar penghasilan serta dapat membantu orang lain dengan memberikan mereka kesempatan bekerja pada bisnis kita.

\section{REFERENSI}

Adiandari, A. M., Yuliani, \& Winata, H. (2019). Personality traits, entrepreneurial self efficacy and financial capability effects on entrepreneurial intention. International Journal of Engineering and Advanced Technology, 8(5C). https://doi.org/10.35940/ijeat.E1142.0585C19

Alfaruk, M. H. (2017). Pengaruh Pemanfaatan Sosial Media, Motivasi Dan Pengetahuan Terhadap Minat Berwirausaha Pada Mahasiswa Ekonomi Di Universitas Muhammadiyah Sidoarjo. Jurnal Ekonomi Pendidikan Dan Kewirausahaan, 4(2), 164-172. https://doi.org/10.26740/jepk.v4n2.p164-172

Alma, B. (2014). Kewirausahaan untuk mahapeserta didik dan umum. Bandung: CV. Alfabeta.

Ariyanto, D. (2020). Influence of justice, culture and love of money towards ethical perception on tax evasion with gender as moderating variable. Journal of Money Laundering Control, 23(1), 245-266. https://doi.org/10.1108/JMLC-06-20190047

Ariyanto, D., Subroto, B., Purnomosidhi, B., \& Rosidi. (2014). Does the Balinese Tri Hita Karana Culture Affect the Adoption and Usage of Information Technology Systems? Information and Knowledge Management.

Cross, M. (2013). Social Media Security: Leveraging Social Networking While Mitigating Risk. Social Media Security: Leveraging Social Networking While Mitigating Risk. https://doi.org/10.1016/C2011-0-09032-4

Elqadri, Z. M., Priyono, P., Suci, R. P., \& Chandra, T. (2015). Effect of Leadership Style, Motivation, and Giving Incentives on the Performance of Employees-PT. Kurnia Wijaya Various Industries. International Education Studies, 8(10), 19131920. https://doi.org/10.5539/ies.v8n10p183

Giantari, N. L. P. D., \& Ramantha, I. W. (2019). Pengaruh Motivasi, Lingkungan Keluarga dan Pendidikan Terhadap Minat Berwirausaha Mahasiswa Jurusan Akuntansi Reguler. E-Jurnal Akuntansi, 28(1), 1-25. https://doi.org/10.24843/eja.2019.v28.i01.p01 
Kompas.com. (2016). Menggenjot Jumlah Ideal Pelaku Wirausaha Indonesia. Retrieved January 28, 2018, from http://ekonomi.kompas.com

Kotler, P. (2012). Marketing management. Pearson Education International.

Kotler, P., \& Keller, K. L. (2016). A Framework for Marketing Management. Marketing Management.

Kurniawan, Y. R., \& Harti. (2013). Pengaruh Tingkat Penggunaan Sosial Media terhadap Minat Berwirausaha Pada Mahasiswa Pendidikan Ekonomi Universitas Negeri Surabaya. Jurnal Pendidikan Tata Niaga, 1(3), 1-17.

Muljaningsih, S., Soemarno, Hadiwidjojo, D., \& Mustadjab, M. M. (2012). FaktorFaktor Yang Mempengharuhi Minat Wirausaha Pengolahan Pangan Organik Pada Perempuan Tani Di Desa Wonokerto, Bantur, Malang. Wacana, 15(2), 2-18.

Myfield, A. (2008). Pendidikan Kewirausahaan (Konsep dan Strategi). Yogyakarta: Pustaka Pelajar.

Praisti, V. O., \& Rusdarti. (2018). Pengaruh Praktik Kerja Lapangan, Motivasi Belajar, Sosial Ekonomi Orangtua Terhadap Minat Berwirausaha. Economic Education Analysis Journal.

Sa'adah, L., \& Mahmud, A. (2019). Pengaruh Penggunaan Instagram Dan Efikasi Diri Melalui Motivasi Berwirausaha Terhadap Minat Berwirausaha. Economic Education Analysis Journal, 8(1), 18-32.

Santoso, S. (2016). Kewirausahaan. Jakarta: PT Raja Grafindo Persada.

Sari, N. P. S. K., \& Sriathi, A. . A. (2019). Peran Motivasi Kerja Memediasi Pengaruh Pengembangan Karir Terhadap Kinerja Karyawan Fairmont Sanur Beach Hotel. E-Jurnal Manajemen Universitas Udayana, 8(8), 4788-4814. https://doi.org/10.24843/ejmunud.2019.v08.i08.p03

Schunk, D. H., Pintrich, P. R., \& Meece, J. L. (2015). Motivasi dalam Pendidikan Teori, Penelitian dan Aplikasi. Jakarta: PT Indeks.

Siagian, H. S., \& Harefa, A. (2019). Hubungan Gaya Kepemimpinan Kepala Ruangan Dengan Kinerja Perawat Di Rumah Sakit Umum Imelda Pekerja Indonesia Medan Tahun 2018. Jurnal Ilmiah Farmasi Imelda.

Sugiyono. (2017). Metode Penelitian Bisnis. Bandung: CV. Alfabeta. 
Sumadi, A. R., \& Sulistyawati, E. (2017). Pengaruh Sikap, Motivasi, Dan Lingkungan Terhadap Niat Berwirausaha. E-Jurnal Manajemen Unud, 6(2), 1007-1029. Retrieved from https://ojs.unud.ac.id/index.php/Manajemen/article/view/27472/17737

Sumerta, I. K., WIdyagoca, I. G. P. A., Adiandari, A. M., \& Herlambang, P. G. D. (2019). Analysis of Technology Acceptance Model (TAM) to Use E-Money in Bali Province. International Journal of Advanced Trends in Computer Science and Engineering (IJATCE), 8(1.5), 206-211.

Sumerta, I. K., Widyagoca, I. G. P. A., \& Meryawan, I. W. (2019). Online Consumer Behavior on Using Social Media on E-Commerce, based on the AISAS Model Approach. Case Study; Bukalapak, Tokopedia and Blili.com. International Journal of Advanced Trends in Computer Science and Engineering (IJATCE)., 8(1.5), 234-242. 